\title{
COMPARISON OF LUTEAL FUNCTION IN PSEUDOPREGNANT AND PREGNANT HAMSTERS
}

\author{
JANINA H. LUKASZEWSKA AND G. S. GREENWALD \\ Departments of Obstetrics and Gynecology and Anatomy, \\ University of Kansas Medical Center, Kansas City, Kansas, U.S.A.
}

(Received 12th May 1969)

The functional status of corpora lutea (CL), as inferred by their weight and progesterone content, was evaluated in pregnant and pseudopregnant golden hamsters. In addition, the duration of pseudopregnancy was determined in intact hamsters and in animals made pseudopregnant by separating the uterus from the ovary. Pseudopregnancy was induced in (1) intact hamsters by mating them to vasectomized males, (2) hamsters in which utero-tubal connections were interrupted either bilaterally or unilaterally, (3) animals which were hysterectomized at least 8 days before mating. In all cases, the day spermatozoa were found in the vaginal smear was designated Day 1 of pregnancy or pseudopregnancy. CL were dissected from the ovaries and weighed; progesterone was determined by the competitive binding method (Neill, Johansson, Datta \& Knobil, 1967). The end-point for the termination of pseudopregnancy was the reappearance of the conspicuous postovulatory vaginal discharge.

The data in Table 1 show that on Day 7, the mean weight per CL of Group 1 hamsters was significantly lower than the other groups according to the honestly significant difference procedure (Steel \& Torrie, 1960). Similarly, on

TABLE 1

COMPARISON OF GL IN THE PSEUDOPREGNANT AND PREGNANT HAMSTER

\begin{tabular}{|c|c|c|c|c|c|c|}
\hline \multirow[t]{2}{*}{ Treatment group } & \multicolumn{3}{|c|}{ Mean wt/CL $(m g \pm S . E)}$. & \multicolumn{3}{|c|}{$\begin{array}{c}\text { Mean progesterone } \\
\text { content/CL (ng } \pm \text { S.E. })\end{array}$} \\
\hline & $\begin{array}{l}\text { No. of } \\
\text { hamsters }\end{array}$ & Day 7 & Day 11 & $\begin{array}{l}\text { No. of } \\
\text { hamsters }\end{array}$ & Day 7 & Day 11 \\
\hline $\begin{array}{l}\text { 1. Pseudopregnant (mated to } \\
\text { vasectomized male) }\end{array}$ & 12 & $\begin{array}{l}0.52^{*} \\
\pm 0 \cdot 02\end{array}$ & - & 6 & $\begin{array}{r}11 \cdot 5^{*} \\
\pm 1 \cdot 01\end{array}$ & - \\
\hline $\begin{array}{l}\text { 2. Pseudopregnant (tract cut } \\
\text { at utero-tubal junction) }\end{array}$ & 11 & $\begin{array}{r}0.62 \\
\pm 0.01\end{array}$ & 一 & 6 & $\begin{array}{l}12 \cdot 5 \\
\pm 0 \cdot 66\end{array}$ & - \\
\hline $\begin{array}{l}\text { 3. Pseudopregnant } \\
\text { (hysterectomized) }\end{array}$ & 9 & $\begin{array}{r}0.63 \\
\pm 0.02\end{array}$ & $\begin{array}{l}0.73^{*} \\
\pm 0.02\end{array}$ & 6 & $\begin{array}{r}11 \cdot 2^{*} \\
\pm 0.92\end{array}$ & $\begin{array}{r}11.9^{*} \\
\pm 0.51\end{array}$ \\
\hline 4. Pregnant & 7 & $\begin{array}{r}0.65 \\
\pm 0.03\end{array}$ & $\begin{array}{r}1.07 \\
\pm 0.04\end{array}$ & 6 & $\begin{array}{c}14 \cdot 6 \\
\pm 0 \cdot 26\end{array}$ & $\begin{array}{c}17 \cdot 1 \\
\pm 1 \cdot 25\end{array}$ \\
\hline
\end{tabular}

$* P<0.05$ in comparison with Group 4.

Day 7, the average progesterone content in Groups 1 and 3 differed significantly from pregnant animals. There was a trend towards reduced progesterone content in Group 2 but the values were not significantly different from the $\mathrm{CL}$ 
of pregnancy. On Day 11, the GL in animals from Group 3 were significantly smaller and contained less progesterone than in pregnant animals.

From the data presented in Table 2, it can be seen that the CL from the ovary adjacent to a pregnant uterine horn were significantly heavier than their counterparts in the contralateral ovary (Group la and b). The average cL

TABLE 2

COMPARISON OF GL FROM OVARIES ADJACENT TO A GRAVID OR A STERILE HORN

\begin{tabular}{|c|c|c|c|c|}
\hline \multirow[b]{2}{*}{ Group } & \multicolumn{2}{|c|}{ Day 8} & \multicolumn{2}{|c|}{ Day 10} \\
\hline & $\begin{array}{c}\text { No. of } \\
\text { hamsters }\end{array}$ & $\begin{array}{l}\text { Mean wt/CL } \\
(m g \pm S . E .)\end{array}$ & $\begin{array}{c}\text { No. of } \\
\text { hamsters }\end{array}$ & $\begin{array}{c}\text { Mean wt/CL } \\
(m g \pm S . E .)\end{array}$ \\
\hline $\begin{array}{l}\text { 1. Unilaterally pregnant } \\
\text { a. ovary adjacent to a pregnant horn } \\
\text { b. ovary adjacent to a sterile horn } \\
\text { 2. Bilaterally pregnant } \\
\text { 3. Bilaterally pseudopregnant }\end{array}$ & $\begin{array}{l}6 \\
6 \\
8 \\
6\end{array}$ & $\begin{array}{l}0 \cdot 79 \pm 0 \cdot 05 \\
0 \cdot 64^{*} \pm 0 \cdot 03 \\
0 \cdot 74 \pm 0 \cdot 03 \\
0 \cdot 61^{*} \pm 0 \cdot 03\end{array}$ & $\begin{array}{r}8 \\
7 \\
11 \\
-\end{array}$ & $\begin{array}{l}0.95 \pm 0.07 \\
0.74^{*} \pm 0.05 \\
0.98 \pm 0.03 \\
-\end{array}$ \\
\hline
\end{tabular}

* $P<0.05$ in comparison with group 2.

weight from the ovary next to a sterile horn in unilaterally pregnant animals did not differ from the value in bilaterally pseudopregnant hamsters (Groups $1 \mathrm{~b}$ and 3 ). However, the $\mathrm{cL}$ from the former group continued to grow between Days 8 and 10, whereas the pseudopregnant animals reverted to oestrus by Day 10 and the CL regressed.

Table 3 presents a comparison of the lengths of pseudopregnancy for intact females mated to vasectomized males (Pseudopregnant 1); for animals in which the utero-tubal junctions were cut and ligated without disrupting the blood

TABLE 3

COMPARISON OF DURATION OF PSEUDOPREGNANCY

\begin{tabular}{l|c|c}
\hline \multicolumn{1}{c|}{ Group } & $\begin{array}{c}\text { No. of } \\
\text { hamsters }\end{array}$ & $\begin{array}{c}\text { Mean duration of pseudopregnancy } \\
\text { (days } \pm \text { S.E. })\end{array}$ \\
\hline Pseudopregnant I & 10 & $8 \cdot 9 \pm 0 \cdot 10$ \\
Pseudopregnant II & 10 & $10 \cdot 0 \pm 0 \cdot 15$ \\
Pseudopregnant III & 10 & $10 \cdot 9 \pm 0.41$ \\
\hline
\end{tabular}

supply (Pseudopregnant II); and for animals in which both the utero-tubal junctions were cut and the blood supply was interrupted between the uterus and ovary (Pseudopregnant III).

Significant differences existed between all groups in the duration of pseudopregnancy, according to the honestly significant difference test $(P<0.05)$. The intact hamsters (Pseudopregnant I) had the shortest pseudopregnancy, i.e. the fastest cessation of luteal function.

Collectively, the present experiments indicate that the cL of pregnancy are larger and produce more progesterone than the CL of pseudopregnancy. Luteal function in pseudopregnant hamsters parallels that of pregnant animals for a few days and thereafter uterine influence and/or lack of placental development suppresses growth and progesterone synthesis in intact pseudopregnant animals. 
The separation of uterus and ovaries prolongs luteal activity by one day; this agrees with Orsini's findings (1969). Further dissociation by interrupting the blood supply between uterus and ovary, extends luteal function beyond 10 days.

CL of pseudopregnant, hysterectomized animals are the same size on Day 7 as CL of pregnancy but their progesterone content is lower. A possible explanation is that there are reduced pituitary levels of FSH in pseudopregnant, hysterectomized hamsters compared to pregnant animals (Greenwald, unpublished) and FSH is an important component of the luteotrophic complex in this species (Greenwald \& Rothchild, 1968).

On Day 11, cL of pseudopregnant, hysterectomized hamsters are smaller and contain less progesterone than CL of pregnancy. Based on ovarian histology, the diameter of $\mathrm{CL}$ in pseudopregnant, hysterectomized hamsters is smaller than in comparable pregnant animals (Orsini, 1969). The size and progesterone production by hamster CL during the second half of pregnancy depends on both hypophysial and placental gonadotrophins and it is noteworthy that hysterectomy during the second half of pregnancy results in prompt regression of the CL (Greenwald \& Rothchild, 1968).

In the unilaterally pregnant hamster, the cL in the ovary adjacent to the sterile horn continue to grow but they never reach the size of the cL on the pregnant side. The sterile uterine horn possesses either limited luteolytic activity or the levels of circulating luteotrophins in the pregnant animal are sufficiently high to counteract a luteolytic factor. Another possibility is that a placental factor locally stimulates CL growth in the adjacent ovary.

J.H.L. was supported as a Ford Foundation Postdoctoral Fellow in Reproductive Biology. The research was supported by grants from N.I.H. (HD-00596) and the Ford Foundation.

\section{REFERENCES}

Greenwald, G. S. \& RothChiLd, I. (1968) Formation and maintenance of corpora lutea in laboratory animals. F. Anim. Sci., Suppl. 1, 27: 139.

Neill, J. D., Johansson, E.D. B., Datta, J. K. \& Knobil, E. (1967) Relationship between the plasma levels of luteinizing hormone and progesterone during the normal menstrual cycle. $\mathcal{J}$. clin. Endocr. 27, 1167.

Orsint, M. W. (1969) Effect of hysterectomy on hamster corpora. (Abstract). Anat. Rec. 163, 238.

Steel, R. G. D. \& Torrie, J. H. (1960) Principles and procedures of statistics. McGraw Hill, New York. 